\title{
EFFECT OF AMINOGLUTETHIMIDE ON REPRODUCTIVE PROCESSES IN FEMALE RATS
}

\author{
W. J. EVERSOLE AND D. J. THOMPSON* \\ Department of Life Sciences, Indiana State University, \\ Terre Haute, Indiana 47809, U.S.A.
}

(Received 31st Fanuary 1974)

\begin{abstract}
Summary. Adult female rats injected subcutaneously with $100 \mathrm{mg}$ aminoglutethimide phosphate (AGP) $/ \mathrm{kg} /$ day for 4 weeks failed to become pregnant when placed in cohabitation with males during the last 2 weeks of the injection period. Lower doses depressed the fertility rate and reduced the litter size: the average litter size of three of eleven rats given $50 \mathrm{mg} / \mathrm{kg} /$ day was 4.7 young and of four of eleven rats given $25 \mathrm{mg}$ was $7 \cdot 0$ young. Twenty-nine controls averaged $10 \cdot 1 /$ litter. Doses of $100 \mathrm{mg}$ $\mathrm{AGP} / \mathrm{kg} /$ day stopped vaginal cycling, prevented ovulation in adults, and delayed dissolution of the vaginal membrane in pubertal rats. Histological studies of the ovaries from rats with initial ages of 17 or 21 days which were injected with 25 to $100 \mathrm{mg} \mathrm{AGP} / \mathrm{kg} /$ day for 2 weeks showed an increase in the number and size of vesicular follicles. Treatment of 27-day-old rats with $25 \mathrm{mg} / \mathrm{kg} /$ day for 2 weeks reduced the number of CL and three of four rats given $50 \mathrm{mg}$ had ovaries lacking such bodies; all control ovaries in this group contained CL. These findings are taken as evidence that AGP inhibits ovulation but does not prevent follicular maturation.
\end{abstract}

\section{INTRODUCTION}

Many pharmacological compounds originally developed as anaesthetics, tranquillizers and anticonvulsants modify endocrine structures and functions (see Gaunt, Chart \& Renzi, 1965). Everett (1964) and Everett, Radford \& Holsinger (1964) have presented evidence that compounds such as atropine, pentobarbital, chlorpromazine, morphine, and reserpine block ovulation in the rat by way of an influence on the central nervous system which results in an inhibition of release of gonadotrophin. Quinn (1965) has shown that the anticonvulsant diphenylhydantoin blocks ovulation in the rat and that it may do so by interfering with the neural stimulus responsible for discharge of hypothalamic principles necessary for the release of ovulating hormone from the adenohypophysis.

In routine testing, A. A. Renzi (personal communication) found that the anti-

* Present address: Human Health and Development Laboratories, The Dow Chemical Company, Box 10, Zionsville, Indiana 46077, U.S.A. 
convulsant $\alpha$-(p-aminophenyl)- $\alpha$ ethylgutarimide phosphate (aminoglutethimide phosphate) caused ovarian enlargement in the immature rat. This observation, coupled with the possibility that aminoglutethimide phosphate could affect the nervous system in a pattern similar to that reported for diphenylhydantoin, prompted us to do a series of investigations on possible effects of this compound on vaginal cycling, fertility, ovulation, and ovarian maturation. The results of these investigations form the basis for this report.

\section{MATERIALS AND METHODS}

Mature and immature female rats of the Charles River strain were used in these studies. Rats were injected subcutaneously daily with either $0.9 \% \mathrm{NaCl}$ (controls) or aminoglutethimide phosphate (AGP) dissolved in saline; the $\mathrm{pH}$ of all such solutions was adjusted to 3.5 to 4.0 since AGP is known to precipitate out of solutions above $\mathrm{pH} 4$. The compound was administered in doses ranging from 25 to $100 \mathrm{mg} / \mathrm{kg}$ and in most cases the concentration was modified so that the volume of fluid injected remained fairly constant. Studies were conducted on vaginal oestrous cycling, vaginal membrane opening, fertility, ovulation, and ovarian weight and microscopic structure. The numbers of animals used in most phases of the study are indicated in the Tables; in general, five to eleven animals were used in both control and treated groups for each parameter investigated. In the vaginal cycling studies, mature virgins rats were injected for 14 days with either saline (controls) or $100 \mathrm{mg} \mathrm{AGP} / \mathrm{kg} / \mathrm{day}$; they were then placed with males and the injections were continued for another 2-week period. Vaginal smears were taken daily during the first 23 days of the experiment. A drop of $10 \%$ acetic acid was added to the rinsings as an aid in distinguishing nuclei of different cell types under low power magnification $(\times 100)$.

Mature virgin rats were used in fertility studies: they were injected for 2 weeks and then placed in cages with mature males so that the ratio was at least one male to three females. After I week, the males were changed so that each female was exposed to two different males in the course of the last 2 weeks of the 4-week period of injections. The females were then placed in individual maternity cages and kept for at least 1 more month. This allowed more than sufficient time for the animals to exhibit signs of pregnancy and to litter if they were going to do so during normal gestation time. Three different dosage levels of AGP, ranging from $25 \mathrm{mg}$ to $100 \mathrm{mg} / \mathrm{kg}$ were used in this series and the experimental design is shown in Table 3.

Mature virgins were used for determining ovulation by the technique of counting tubal ova (Rowlands, 1942; Everett \& Sawyer, 1950; Zarrow, Caldwell, Hafez \& Pincus, 1958). The rats were subjected to $14 \mathrm{hr}$ light/10 hr dark per day. Vaginal smears were taken daily and eleven rats which showed at least two previous 4-day cycles were chosen for experimentation. A single intraperitoneal injection of saline was given to each of six controls; five rats were injected similarly with $100 \mathrm{mg} \mathrm{AGP} / \mathrm{kg}$ between 13.00 and 14.00 hours on the day of pro-oestrus (approximately $3 \mathrm{hr}$ before the time of neurohumoral stimulation of $\mathrm{LH}$ release). The following morning vaginal smears were taken before autopsy. The oviducts were compressed under a coverslip and the wet 
mount was examined for ova, first with the dissecting scope $(\times 10)$ and then with compound lenses $(\times 100)$.

Three groups of immature rats, 17 to 27 days of age, were used in studies involving ovarian weight and microscopic structure. Group 1 consisted of eighteen 17-day-old animals, six of which received $75 \mathrm{mg} \mathrm{AGP} / \mathrm{kg}$, six received $100 \mathrm{mg} / \mathrm{kg}$, and six served as controls. Group 2 contained eighteen 21-day-old rats, six of which received $25 \mathrm{mg} \mathrm{AGP} / \mathrm{kg}$, six $50 \mathrm{mg} / \mathrm{kg}$, and six served as controls. Group 3 was composed of eighteen 27-day-old rats which received the same dosages as those in Group 2. All rats were injected daily for 14 days and were killed on Day 15. After their removal, the ovaries were separated from the oviducts, trimmed of fat under a dissecting microscope, and weighed on an analytical balance. They were then fixed in Bouin's fluid, mounted in paraffin wax, sectioned at $10 \mu \mathrm{m}$, and stained with haematoxylin and eosin. The ovaries of animals from Group 1 were serially sectioned and every tenth section was studied. In the other groups, representative sections from the mid-region of each ovary were processed and counts were made of vesicular follicles and CL. The diameters of vesicular follicles in mid-ovarian sections were determined for Group 3 with the aid of an ocular micrometer.

\section{RESULTS}

All animals treated with AGP recovered from depressive effects within $6 \mathrm{hr}$ after injection and drank and ate avidly during the post-recovery period. Gross signs of torpor and ataxia occurred only with the highest dose $(100 \mathrm{mg} /$ $\mathrm{kg}$ ). At all the dosage levels, the treated rats showed a greater mean percentage gain in body weight than the controls (Table 1), but the gain was not significant in the rats receiving $25 \mathrm{mg}$ in Group 3.

\section{Vaginal cycles}

Representative findings of the effects of AGP $(100 \mathrm{mg} / \mathrm{kg}$ ) on vaginal cycling and smears are illustrated in Text-fig. 1. It can be seen that control Rat A had a 4-day cycle, and a vaginal plug was found 5 days after exposure to males; this rat became pregnant and produced a normal litter. Control Rat B exhibited a cycle that departed from the usual 4-day pattern: typical oestrous smears were obtained and the animal produced a normal litter even though no vaginal plug was observed. All treated females failed to cycle normally and exhibited two major types of vaginal events which are illustrated by Rats $G$ and $D$. Rat $\mathrm{C}$ had primarily anoestrous-type smears for 23 days and failed to show indications of oestrus following the 2nd day of treatment. Smears from Rat D were bizzare and difficult to classify: nucleated epithelial cells were abundant on Days 9 to 14 and Days 18 to 20 but the typical oestrous smear with large masses of clumped non-nucleated cells was never observed. These 'mixed' smears contained numerous leucocytes as well as small clumps of nucleated epithelial cells. The data on cycling for all rats are summarized in Table 2. In general, control rats exhibited typical oestrous smears, most of them cycled regularly and, when mated, produced normal litters. None of the treated animals had typical oestrous smears or cycles; but four of eleven rats had mixed smears. 
During treatment and exposure to males, none of these rats became pregnant. One week after cessation of treatment, normal smears were seen and typical cycling resumed.

Table 1. Effects of AGP on body weight in three groups of immature female rats

\begin{tabular}{c|c|c|c|c}
\hline $\begin{array}{c}\text { Group } \\
\text { (initial age) }\end{array}$ & $\begin{array}{c}\text { No. } \\
\text { of } \\
\text { rats }\end{array}$ & $\begin{array}{c}\text { Dose of } \\
A G P \\
(\mathrm{mg} / \mathrm{kg} / \text { day })\end{array}$ & $\begin{array}{c}\text { Initial mean } \\
\text { body wot } \\
(\mathrm{g})\end{array}$ & $\begin{array}{c}\text { Mean \% wt gain } \\
(14 \text { days of treatment })\end{array}$ \\
\hline 1 (17 days) & 6 & 0 & 28 & 192 \\
Control & 6 & 75 & 25 & 231 \\
Treated & 6 & 100 & 30 & 253 \\
Treated & 7 & & & 141 \\
2 (21 days) & 6 & 0 & 48 & 153 \\
Control & 6 & 25 & 47 & 156 \\
Treated & 6 & 50 & 46 & 82 \\
Treated & 6 & & & 86 \\
3 (27 days) & 5 & 0 & 74 & 102 \\
Control & 5 & 25 & 71 & \\
Treated & 5 & 50 & 64 & \\
Treated & 4 & & & \\
\hline
\end{tabular}

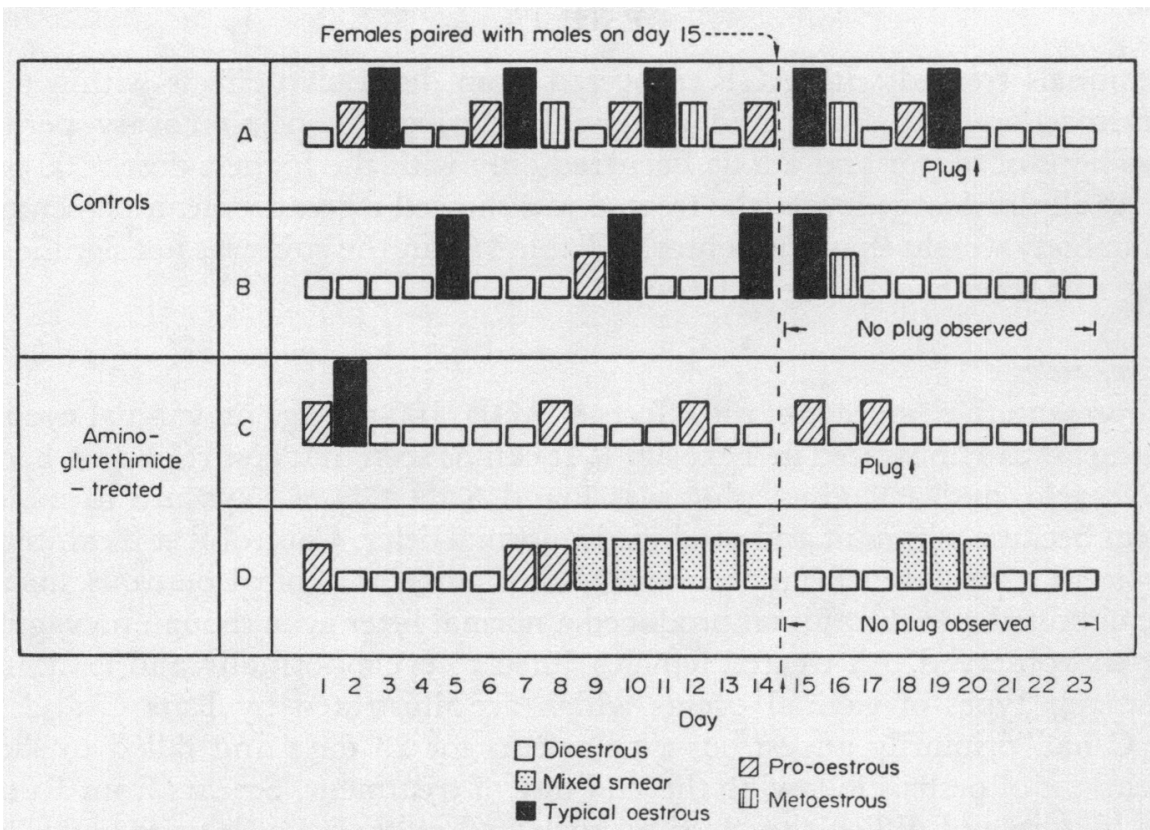

TEXT-FIG. 1. Vaginal smears in individual rats: (A) typical control, (B) irregular control,

(C) AGP-treated, anoestrous type, (D) AGP-treated, atypical oestrous (mixed) type.

\section{Vaginal opening}

Rats were 27 days of age at the time injections were started. Dissolution of the vaginal membrane was delayed by drug treatment since the mean age for vaginal opening in the controls was 34 days, whereas it was 37 and 39 days after doses of 25 and $50 \mathrm{mg} / \mathrm{kg}$ respectively. 
Fertility studies

As can be seen in Table 3, AGP had antifertility action in females at dosage levels ranging from 25 to $100 \mathrm{mg} / \mathrm{kg}$ day and pregnancy was suppressed completely with the highest dose. In the second experiment in this series, where $50 \mathrm{mg}$ AGP $/ \mathrm{kg}$ was used, eight of eleven treated animals failed to litter. One month after cessation of treatment, these eight females were exposed to males again and all became pregnant and produced normal litters. The three females which became pregnant during treatment gave birth to a total of fourteen young, six normal males and eight normal females. These were raised to maturity and randomly inbred. All female offspring from treated mothers became pregnant and delivered normal litters.

Table 2. Effects of AGP on vaginal cycles in rats

\begin{tabular}{l|c|c|c|c|c}
\hline \multicolumn{1}{c|}{ Treatment } & $\begin{array}{c}\text { No. } \\
\text { of } \\
\text { rats }\end{array}$ & $\begin{array}{c}\text { No. with } \\
\text { regular } \\
\text { cycles }\end{array}$ & $\begin{array}{c}\text { No. with } \\
\text { irregular } \\
\text { cycles }\end{array}$ & $\begin{array}{c}\text { No. showing } \\
\text { oestrous } \\
\text { smears }\end{array}$ & $\begin{array}{c}\text { No. } \\
\text { pregnant }\end{array}$ \\
\hline Controls & 11 & 9 & 2 & 11 & 10 \\
AGP $(100 \mathrm{mg} / \mathrm{kg} /$ day for 28 days $)$ & 11 & 0 & No cycles & $0^{*}$ & 0 \\
\hline
\end{tabular}

* Four rats exhibited 'mixed' smears.

Table 3. Effects of AGP on fertility in rats

\begin{tabular}{l|c|c|c}
\hline \multicolumn{1}{c|}{ Treatment } & $\begin{array}{c}\text { No. } \\
\text { of } \\
\text { females }\end{array}$ & $\begin{array}{c}\text { No. } \\
\text { producing } \\
\text { litters }\end{array}$ & $\begin{array}{c}\text { Average } \\
\text { no. of } \\
\text { young/litter }\end{array}$ \\
\hline None & 11 & 8 & $9 \cdot 8$ \\
AGP, $25 \mathrm{mg} / \mathrm{kg} /$ day & 11 & 4 & 7.0 \\
None & 11 & 11 & 10.4 \\
AGP, $50 \mathrm{mg} / \mathrm{kg} /$ day & 11 & 3 & $4 \cdot 7$ \\
None & 11 & 10 & $10 \cdot 1$ \\
AGP, $100 \mathrm{mg} / \mathrm{kg} /$ day & 11 & 0 & 0.0 \\
\hline
\end{tabular}

AGP was injected subcutaneously daily for 4 weeks. Males were placed with the females during the last 2 weeks of treatment.

Tubal ova counts

No ova were found in the oviducts of treated rats and smear studies indicated that AGP maintained the animals in the pro-oestrous condition from the time of injection until autopsy ( $20 \mathrm{hr}$ after injection). All controls were in oestrus, their oviducts were distended and difficult to separate from the ovary, and ova were found in their tubes.

\section{Ovarian weight and structure}

Treatment of 17- and 21-day-old rats resulted in ovarian enlargement of questionable statistical significance but an increase in the number of vesicular follicles was highly significant (Table 4). Photographs of ovarian sections illustrate the contrast between control and experimental ovaries (PI. 1, Figs 
1 and 2). As seen in Table 4, treatment of older animals (Group 3) resulted in a decreased number of CL. Plate 1, Fig. 3 illustrates a section from a control ovary showing numerous CL and Fig. 4 shows a section from an experimental ovary in which no CL were found. The number and size of CL correlated well with ovarian weight: the heavier control ovaries contained many, whereas lighter ovaries from treated rats had few, CL. The 50-mg dose increased the number of vesicular follicles in the rats of Group 3 but the 25-mg dose was ineffective.

Table 4. Effects of 14 days of AGP treatment on ovarian weight and structure in rats

\begin{tabular}{|c|c|c|c|c|c|c|}
\hline $\begin{array}{c}\text { Group } \\
\text { (initial age) }\end{array}$ & $\begin{array}{c}\mathcal{N} \text { o. } \\
\text { of } \\
\text { rats }\end{array}$ & $\begin{array}{c}\text { Dose of } \\
A G P \\
(m g / k g / d a y)\end{array}$ & $\begin{array}{c}\text { Ovarian wt } \\
(m g / 100 g \\
\text { body wt }) \\
(\text { Mean } \pm \text { S.E. })\end{array}$ & $\begin{array}{c}\text { No. } \\
\text { of } \\
\text { sections } \\
\text { studied }\end{array}$ & $\begin{array}{c}\text { No. of vesicular } \\
\text { follicles per } \\
\text { section } \\
(\text { Mean } \pm S . E .)\end{array}$ & $\begin{array}{c}\text { No. of } \\
\text { CL per } \\
\text { section } \\
\text { (Mean } \pm S . E .)\end{array}$ \\
\hline $\begin{array}{l}\text { Group } 1 \\
\text { (17 days old })\end{array}$ & & & & & & \\
\hline $\begin{array}{l}\text { Control } \\
\text { Treated }\end{array}$ & $\begin{array}{l}6 \\
6 \\
7\end{array}$ & $\begin{array}{r}0 \\
75\end{array}$ & $21 \cdot 1 \pm 0.99$ & $\begin{array}{l}34 \\
29\end{array}$ & $\begin{array}{c}9.0 \pm 0.44 \\
16.0 \pm 0.56^{*}\end{array}$ & $\begin{array}{l}0 \\
0\end{array}$ \\
\hline $\begin{array}{l}\text { Treated } \\
\text { Group } 2\end{array}$ & 7 & 100 & 24. & 43 & $20 \cdot 2$ & 0 \\
\hline $\begin{array}{l}\text { Control } \\
\text { Treated } \\
\text { Treated }\end{array}$ & $\begin{array}{l}6 \\
6 \\
6\end{array}$ & $\begin{array}{r}0 \\
25 \\
50\end{array}$ & $\begin{array}{l}21 \cdot 2 \pm 2 \cdot 82 \\
23 \cdot 6 \pm 1 \cdot 90 \\
25 \cdot 7 \pm 5 \cdot 16\end{array}$ & $\begin{array}{l}26 \\
29 \\
23\end{array}$ & $\begin{array}{c}8.6 \pm 0 \cdot 64 \\
18 \cdot 7 \pm 0 \cdot 87^{*} \\
18 \cdot 2 \pm 1.23^{*}\end{array}$ & $\begin{array}{c}0 \\
0 \\
0 \cdot 50 \pm 0 \cdot 19\end{array}$ \\
\hline $\begin{array}{l}\text { Group } 3 \\
\text { (27 days old) }\end{array}$ & & & & & & \\
\hline $\begin{array}{l}\text { Control } \\
\text { Treated } \\
\text { Treated }\end{array}$ & $\begin{array}{l}5 \\
5 \\
4\end{array}$ & $\begin{array}{r}0 \\
25 \\
50\end{array}$ & $\begin{array}{l}29 \cdot 4 \pm 2 \cdot 48 \\
26 \cdot 8 \pm 1 \cdot 89 \\
24 \cdot 8 \pm 5 \cdot 86\end{array}$ & $\begin{array}{l}72 \\
47 \\
64\end{array}$ & $\begin{array}{c}6.0 \pm 0.36 \\
5.9 \pm 0.25 \\
15.8 \pm 0.84^{*}\end{array}$ & $\begin{array}{l}5 \cdot 20 \pm 0 \cdot 17 \\
2 \cdot 23 \pm 0 \cdot 12^{*} \\
0 \cdot 31 \pm 0 \cdot 13^{*}\end{array}$ \\
\hline
\end{tabular}

* Significantly different from controls $(P<0 \cdot 01)$.

Observations on ovaries taken from rats in Group 3 revealed that $50 \mathrm{mg}$ AGP/ $\mathrm{kg}$ caused an increase in size of vesicular follicles. Control ovaries contained no more than two follicles per ovary with diameters greater than $400 \mu \mathrm{m}$, whereas ovaries from treated animals had twelve or more follicles per ovary with diameters greater than $400 \mu \mathrm{m}$; several follicles exceeded $1000 \mu \mathrm{m}$ in diameter.

\section{DISCUSSION}

Aminoglutethimide phosphate has been shown in this study to modify reproductive processes in the female rat. These modifications were shown to be temporary in nature since vaginal cycling, conception and birth of normal young occurred in females following cessation of a 4-week treatment period. The antifertility and antiovulatory actions of AGP resemble those of diphenylhydantoin (DPH), a well-known anticonvulsant. On the basis of results obtained after LH injections and hypothalamic manipulations, Quinn (1965) concluded that low doses of DPH (50 to $150 \mathrm{mg} / \mathrm{kg}$ ) interfered with the neural stimulus for the discharge of hypothalamic principles and that high doses $(175 \mathrm{mg} / \mathrm{kg})$ interfered with ovulation at a peripheral site in addition to any influence it 


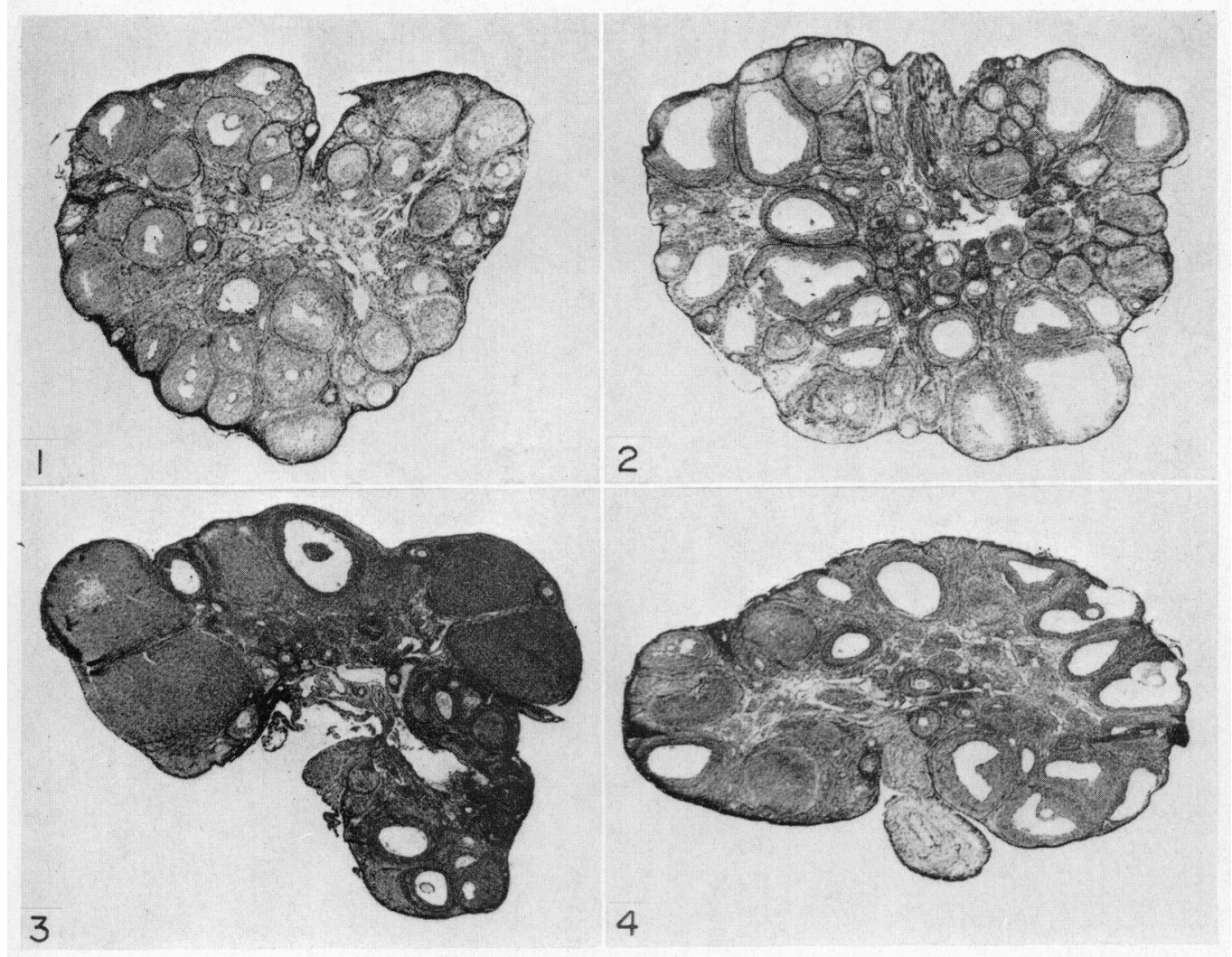

FIGs 1 to 4 . Rat ovary sections $(\times 30)$.

FiG. 1. Section of 32-day control ovary. Note small follicles and no GL.

Frc. 2. Section of 32-day ovary from rat treated daily for 14 days with $75 \mathrm{mg} \mathrm{AGP/kg}$. Note numerous vesicular follicles.

Fig. 3. Section of 42-day control ovary. Note numerous CL.

Fig. 4. Section of 42-day ovary from rat treated daily for 14 days with $25 \mathrm{mg} \mathrm{AGP} / \mathrm{kg}$. Note absence of typical CL.

(Facing p. 130) 
may have exerted upon the median preoptic area. In the present studies, no attempts were made to localize the site of action of AGP but it appears to be a more potent ovulation-blocking agent than DPH since a $100 \mathrm{mg} / \mathrm{kg}$ dose completely inhibited fertility and prevented CL formation, and even a dose as low as $25 \mathrm{mg} / \mathrm{kg}$ had appreciable effects on these processes. It is possible that the apparently greater efficacy of AGP as an antifertility compound depends on peripheral rather than central actions. Dexter, Fishman, Ney \& Tiddle (1967) and Sheppard, Beasley \& Wacker (1966) reported that AGP inhibited corticosteroidogenesis and the former authors presented evidence that inhibition occurred before the formation of $\Delta^{5}$-pregnene- $3 \beta$-ol-20-one. On the basis of their studies with this drug on various endocrine organs, Pittman \& Brown (1966) also suggested that AGP might affect ovarian steroidogenesis. The striking inhibitory effects of AGP on vaginal cycling, its delaying action on vaginal membrane dissolution, its effects in increasing weight gain in females, and its lack of inhibitory influence on FSH secretion (judged by follicular development) all point toward a decrease in circulating oestrogen. Such a change would be expected with decrease in ovarian steroidogenesis. The antifertility findings, the tubal ova studies, and the histological evidence for suppression of CL formation support our conclusion that AGP acts as an antiovulatory agent. Pittman \& Brown (1966), using doses of AGP two or five times the highest dose $(100 \mathrm{mg} / \mathrm{kg})$ used here, reported a markedly significant increase in ovarian weight in the intact Sprague-Dawley adult rat. In their report, no attempts were made to study blood gonadotrophin levels or correlate ovarian size with microscopic structure. On the basis of our results, it would be reasonable to assume that the increase in ovarian weight was caused by high levels of circulating FSH and excessive follicular development. Wilbur (1970), working in our laboratories, found that AGP reduced plasma LH concentration in adult female rats. It would appear then that the antifertility actions of AGP are related to depression of blood levels of oestrogen and LH. This suggestion is consistent with the findings of Ying \& Greep (1971) who reported that the AGP block of ovulation in PMSG-treated immature rats could be prevented by administering oestradiol, testosterone, progesterone, or LH.

\section{ACKNOWLEDGMENTS}

The authors are indebted to Dr R. Gaunt and Dr J. J. Chart, Ciba-Geigy, Summit, New Jersey, for generous supplies of aminoglutethimide phosphate and for many helpful suggestions during the course of this study.

\section{REFERENCES}

Dexter, R. N., Fishman, L. M., Ney, R. L. \& Tiddle, G. W. (1967) Inhibition of adrenal corticosteroid synthesis by aminoglutethimide: studies of the mechanism of action. F. clin. Endocr. Metab. $27,473$.

EveretT, J. W. (1964) Central neural control of reproductive functions of the adenohypophysis. Physiol. Rev. 44, 373.

Everett, J. W., RAdFord, H. M. \& Holsinger, J. (1964) Electrolytic irritative lesions in the hypothalamus and other forebrain areas: effects of luteinizing hormone release and the ovarian cycle. Hormonal Steroids, Biochem. Pharmac. Ther. 1, 235.

Everetr, J. W. \& SAWYER, C. H. (1950) A 24-hour periodicity in the "LH-release apparatus" of female rats disclosed by barbiturate sedation. Endocrinology, 47, 198. 
Gaunt, R., Chart, J. J. \& Renzi, A. A. (1965) Inhibitors of adrenal cortical function. Ergebn. Physiol. $56,114$.

Pittman, J. A. \& Brown, R. W. (1966) Antithyroid and antiadrenocortical activity of aminoglutethimide. F. clin. Endocr. Metab. 26, 1014.

Quins, D. L. (1965) Influence of diphenylhydantoin on spontaneous release of ovulating hormone in the adult rat. Proc. Soc. exp. Biol. Med. 119, 982.

RowLANDS, I. W. (1942) Collection of eggs from the Fallopian tube of a rat. Nature, Lond. 150, 267.

Sheppard, H., BeAsley, J. N. \& WAcker, J. L. (1966) The influence of NADPH or its generating system on corticosteroid biosynthesis by rat adrenal homogenates. Fedn Proc. Fedn Am. Socs exp. Biol. 25, 551, Abstr.

WILBUR, D. L. (1970) Assay of luteinizing hormone in animals treated with anti-ovulatory substances. Physiologist, Wash. 13, 341, Abstr.

YING, S.-Y. \& GREEP, R. O. (1971) Prevention of aminoglutethimide phosphate (AGP) block of ovulation in PMS-treated immature rats. Proc. Soc. exp. Biol. Med. 136, 916.

Zarrow, M. X., Caldwell, A. L., JR, Hafez, E. S. E. \& Pincus, G. (1958) Superovulation in the immature rat as a possible assay for LH and HCG. Endocrinology, 63, 748. 